biomedical and social understanding of HIV / AIDS and ways of dealing with it. Society expects higher education to direct its skilled human resources toward understanding the disease in all its dimensions. The hope is that the newly generated knowledge will lead to solutions, interventions, and programs that will contribute to rolling back the progress of the epidemic.

Finally, higher education should work with public and private agencies and with individuals to confront the destructive power of the epidemic. Higher education needs to provide the knowledge and understanding and draw upon the hands-on experiences of agencies, communities, and individuals to identify and solve the problems that need to be addressed.

The bottom line for higher education is that it should care about the epidemic both within its own community and in the world. One day history will judge the adequacy of higher education's response in the face of the most devastating catastrophe that humanity has ever experienced.

\section{A Decade of Transatlantic Cooperation}

\section{Hans de Wit}

Hans de Wit is senior adviser for international affairs at the University of Amsterdam. He is also editor of the Journal of Studies in International Education. E-mail: j.w.m.deWit@uva.nl.

$I^{\mathrm{n}}$ n 1993, a pilot program was started to promote transatlantic cooperation between institutions of higher education in the countries of the European Union (EU) and the United States. This pilot program became an actual one in 1995 and was soon followed by a similar EUCanada program. Ten years later, it is time to look at the rationales behind these initiatives and see if the objectives are still valid in the present context of ongoing European integration under the Bologna process.

\section{Objectives}

In the course of preparing the EU-U.S. pilot program, several experts, including the author, were invited by the European Commission to take part in a meeting to discuss the format of the program.

A number of other programs exist linking higher education in the EU to the rest of the world-such as the Alfa program for Latin America, the Medcampus program for the Mediterranean region, and the Asia Link program. One of the relevant factors pointed out at the meeting was the ongoing active cooperation in higher education between the United States and Europe, both in student and faculty mobility and in research. Thus, a new program would be able to build upon long existing ties and exchanges. The same would to a great extent be true for Canada.

\section{Whereas most of the linkages in higher edu- cation between the two continents are bi- lateral, the new program should create multilateral linkages, building on the expe- rience of the Erasmus program in the EU.}

Given the large numbers of students moving back and forth between the two continents, the main objective would not involve student mobility but rather developing new types of cooperation and enhancing existing relationships by overcoming bureaucratic obstacles. The recognition and portability of credits should be tried as a way of furthering cooperation.

Whereas most of the linkages in higher education between the two continents are bilateral, the new program should create multilateral linkages, building on the experience of the Erasmus program in the EU.

Another recommendation discussed at the meeting was increased cooperation at the graduate level and in areas and disciplines in which traditionally only research collaboration existed-such as the sciences, law, and engineering. Another area requiring enhancement would be cooperation between community colleges in the United States and the nonuniversity sector in the EU. All these ideas would be reflected in the EU-U.S. pilot program.

\section{Rationales}

The main push for cooperation and mobility in higher education between the United States and Europe started after World War II. Previously, the movement of students and faculty occurred mainly from the United States to Europe, but after 1945 most individual mobility was directed from Europe to the United States. Much of the movement from the United States to Europe continues to be at the undergraduate level and in organized junior-year or semester abroad programs.

The emergence of the United States as a superpower after World War II and the Cold War created a need for the United States to learn more about the world. Funding for exchange programs and international curriculum programs was established-such as Fulbright scholarships for student and faculty exchanges and Title VI for area studies and foreign-language 
programs. These programs received support mainly from the Defense Department and the State Department, for reasons of national security and foreign policy.

In Europe, less attention was paid to international exchanges and cooperation since in the first years after the war the focus was on reconstruction and regional economic cooperation and integration. Not until the late 1970s, once the European integration process was well under way, did interest in regional cooperation and mobility lead to the development of programs for research cooperation (the current Framework programs for research and development) and educational cooperation (in particular, the Erasmus program).

Fears of "Fortress Europe," the impact of the end of the Cold War, and the globalization of world economies led to the 1990 Transatlantic Declaration on EU-U.S. Relations, which included the stimulation of cooperation in higher education. This declaration, especially the inclusion of higher education, appears to have been initiated by the United States, which was concerned about the growing attention to cooperation within the European Union and the resulting U.S. isolation from that process. The declaration formed the basis for the EU-U.S. pilot program of 1993-1994 and the current program, which started in 1995.

Political and economic rationales thus formed the basis for this program. Canadians did not wish to be excluded and thus initiated a similar program between Canada and the EU.

The past 10 years have seen an increase, quantitatively and qualitatively, in cooperation and exchange in higher education.

\section{Impact}

The past 10 years have seen an increase, quantitatively and qualitatively, in cooperation and exchange in higher education. The linkages between institutions on both sides of the ocean have increased in number. The cooperative arrangements are more multilateral in scope than before; and larger numbers of students are moving in both directions across the Atlantic. American for-profit providers are entering the European market (e.g., Sylvan Group, Phoenix University). It has become easier to arrange for the recognition and transfer of credits. In general, countries now possess greater knowledge about each other's systems, in particular about the nonuniversity sectors, and there is more cooperation in that sector than before.

One should not, however, overestimate the influence of the EU-U.S. and EU-Canada programs on these developments. The international education market itself, institutional strategies, and national bilateral programs have been more important drivers than these two programs. But the programs have played a role, particularly in the following areas: the increase of multilateral programs, the recognition and portability of credits, cooperation in vocational training, and cooperation in nontraditional fields.

The Bologna process is creating new challenges for higher education cooperation.

\section{The Future}

The Bologna process, which is directed at the creation of a European higher education area, is creating new challenges for higher education cooperation between Europe and North America. These challenges will need to be addressed in the EU-U.S. and EU-Canada programs.

The emergence of a more transparent European higher education system should help to overcome obstacles to the mobility of students. However, this supposed transparency could result in a misunderstanding on the American side with regard to new two-tier system that is being implemented in continental Europe. For example, might a three-year undergraduate program in continental Europe lead American graduate schools to assume that a bachelor's degree earned from such a program does not meet the standards for admission to an American master's program? Or will U.S. graduate schools continue to look at the length and content of the whole educational career of European students and base their admissions policies for graduate schools on these more substantive criteria?

Will European undergraduate students still have the opportunity or the time to undertake a semester or year abroad during their three-year undergraduate degree programs or their one- to two-year master's programs? In the long, single-degree programs under the old system, students had more time to take a semester or year off to do their elective work abroad. The fear is that the new, more tightly designed degree programs will allow for less elective space. Movement within the European higher education area might prove to be easier than going to another system.

Alternatively, will the introduction of a distinction in Europe between undergraduate and graduate programs open more opportunities for American institutions to integrate their junior-semester or -year abroad programs into European universities? U.S. students might be able to move on from the rather 
isolated and protected U.S. study abroad programs that are common in Europe. The introduction of master's programs in Europe may allow for the development of joint degree programs between North American and European graduate schools, programs that until now have been rather difficult to put together.

The next phase of the EU-U.S. and EU-Canada programs could help to address some of these concerns and assist in finding ways of overcoming misunderstandings about the implications of the Bologna process. The EU and the two North American partners might also look into the option of merging the two programs and thereby truly promoting multilateral cooperation to a greater extent.

This article is based on a presentation at the Transatlantic Education and Training Conference, organized by the U.S. Department of Education, the Canadian government, and the European Commission, Lisbon, December 2003.

\section{The "Tipping Point" in International Education:}

\section{How America Is Losing the Race Philip G. Altbach}

Philip G. Altbach is Monan professor of higher education and director of the Center for International Higher Education at Boston College.

A preponderance of little things can add up to a major change. Malcolm Gladwell called this the "tipping point" in his best-selling book of the same title. We are now seeing a tipping point in action in the field of international education. Before our very eyes, the United States is losing its central role as the preferred destination for students and scholars worldwide. Its role as the most influential system may be in jeopardy. The signs of decline are unmistakable. And current decline means future disaster in the highly dynamic and rapidly expanding international education market.

For the first time in decades, the number of international students in the United States has not grown-remaining virtually stagnant at 586,000. The immediate future looks bleak. The Educational Testing Service reports that the numbers taking the Graduate Record Examination are down-minus 50 percent from China, 37 percent from India, 15 percent from South Korea, and 43 percent from Taiwan. These countries are among the largest senders of students to the United States. Many universities report decreases in foreign applications. For example, on my own campus, the Lynch School of Education notes a decline from 88 to 15 applications from China in just one year. Princeton reported a 50 percent decline in Chinese applications and a decline of 28 percent in overall foreign applications. Michigan, Syracuse, Duke, Georgetown, and many others also note steep declines. Fewer applications will mean fewer enrollments.

The world is not a static place, and the United States is not the only player in international higher education.

The world is not a static place, and the United States is not the only player in international higher education. Students and scholars respond to a complex nexus of pushes and pulls when seeking a place to study. The demand for foreign study remains high-about 2 million students studying outside of their home countries now, a number that is likely to grow to 8 million by 2025 . Other countries, such as Australia and the United Kingdom, are especially aggressive in recruiting international students. The European Union, with its Bologna Initiative to harmonize academic systems and encourage cross-border study, is implementing significant change. Japan has been successful in recruiting students from other Asian countries. While the United States stands still or falls behind, other countries are rapidly moving ahead.

\section{Reasons for the Decline}

Tipping points have many causes, and the decline of America's international prominence is no exception. The "tip" occurs when there is a preponderance of precipitating forces. We have now reached the tip. September 11th is a central factor. The increased concern about security, the Patriot Act, and other restrictions have created a profound change in attitudes and perceptions, both within the United States and abroad. The many tales of the difficulties that students and scholars from abroad have in obtaining visas, the perceived disrespect for visa applicants shown at American embassies around the world, and the delays inherent in the entire immigration system have been significant deterrents. Recent attitude surveys as well as a wealth of anecdotal evidence support this. Prospective international students no longer see the United States as a welcoming environment. While foreign students in the United States say that they feel reasonably safe and have few complaints, those abroad thinking about studying in America express fear about safety there as well as criticism of the U.S. system, according to a recent survey. 